\title{
CANDIDO: NA TRAMA DAS LEMBRANÇAS DE DRUMMOND E MURILO*
}

http://dx.doi.org/10.11606/issn.2237-1184.v0i30p172-192

\section{Cleusa Rios P. Passos ${ }^{I}$}

\section{RESUMO}

Em "Poesia e ficção autobiográfica", Antonio Candido aborda a questão da memória em autores mineiros ao longo da história, detendo-se em Carlos Drummond de Andrade, Murilo Mendes e Pedro Nava. A leitura aqui proposta retoma algumas de suas ideias no primeiro e no segundo, elegendo, especificamente, os livros Boitempo I e $A$ idade do serrote, para revelar os fragmentos do vivido, apreendidos a partir de "cenas, casos e emoções", traços específicos do passado de ambos, transfigurados e ressignificados literariamente nas duas obras. E aí entra Candido que, ao sublinhar com agudez pontos fulcrais dos textos de cada um, oferece aos leitores várias direções interpretativas, inclusive a que estabelece relações sutis com a psicanálise. É esse viés que se busca perseguir aqui.

\section{ABSTRACT}

In "Poetry and Autobiographical Fiction" Antonio Candido addresses the issue of memory throughout history in authors from Minas Gerais, focusing particularly in Carlos Drummond de Andrade, Murilo Mendes and Pedro Nava. The approach proposed here retakes some of his ideas about the first and second writers, electing especially the books Boitempo I and A idade do serrote to reveal fragments of the lived apprehended from "scenes, cases and emotions", specific traces of both transfigured and resignified literally in the two books. Thus, here is Candido that, underlining sharply key points in the text of each of these writers, offers readers various interpretive directions including that which establishes subtle relations with psychoanalysis. That is the objective sought here.

\author{
PALAVRAS-CHAVE: \\ Antonio Candido; \\ Carlos Drummond de Andrade; \\ Murilo Mendes; \\ memória; \\ crítica literária e psicanálise.
}

\section{KEYWORDS}

Antonio Candido;

Carlos Drummond de Andrade;

Murilo Mendes;

memory;

literary criticism and

psychoanalysis.

\footnotetext{
* Várias ideias deste ensaio já estão expostas em "Candido e Freud: fragmentos do vivido em Boitempo", in: SCRIPTA. Belo Horizonte: PUC-Minas, v. 23, 2019, p. 49-69, dedicado inteiramente à leitura de Candido sobre o referido livro de Carlos Drummond de Andrade.

I Universidade de São Paulo, São Paulo, São Paulo, Brasil.
} 


\section{ntonio Candido: a "autobiografia" poética e ficcional}

Em "Poesia e ficção autobiográfica", integrante de A educação pela noite $\mathcal{E}$ outros ensaios (1989), Antonio Candido debruça-se sobre autores que compuseram 'autobiografias' em Minas, desde o século XVIII, tendo por objetivo fundamental discutir os textos que ele nomeia "autobiografias poéticas ou ficcionais" e, aí, focaliza produções de três renomados mineiros: Carlos Drummond de Andrade e seus livros Boitempo I (1968) e Boitempo II (Menino antigo, 1973), Murilo Mendes e seu A idade do serrote (1968) e Pedro Nava e seus Baú de Ossos (1972) e Balão cativo (1973).

Tais obras são enfeixadas por um eixo comum: as lembranças, compondo-se cada uma de forma singular. Ainda em comum, está a escrita precisa e clara de Antonio Candido que, em um parágrafo ou expressão, concentra dados substanciais da poética ou prosa dos autores, permitindo ao leitor se aventurar por vias críticas abertas por sua leitura. Além disso, o olhar do ensaísta revela-se na sutileza da escolha teórica, que, sem explicitar nenhum viés crítico, recorre a vários campos do conhecimento, dentre eles, ao pensamento de Freud.

Aliás, aí se destaca a constante relação de fatores socioculturais e psíquicos para a interpretação literária, na busca crítica da escolha de uma perspectiva, ou de várias, no intento de integrar elementos textuais para uma "interpretação coerente", de acordo com sua proposta em Literatura e Sociedade (1973, p. 7). Logo, em "Poesia e ficção autobiográfica", Candido rastreia o viés de uma tradição brasileira, menos enfocada, que se delineia a partir do tema da autobiografia (ou autoficção, em termos mais recentes?), sustentando-se em circunstâncias histórico-sociais e no trabalho textual dos autores referidos, preocupados em evocar instantes e cenas do passado, (re)construídos no presente imaginariamente.

O ensaio de Candido foi, em princípio, uma palestra proferida em Belo Horizonte (março de 1976), publicada com o título "Autobiografia poética e ficcional de Minas" (1989, p. 215) um ano depois, esclarecendo que não se tratava de "autobiografia em geral", mas, sim, de uma "modalidade particular", cujo intento era comentar "alguns livros autobiográficos de cunho francamente poético e ficcional" (Idem, p. 53). Esse dado é importante porque em 1977, dois anos após a apresentação de seu trabalho, Serge Doubrovisky cria, na quarta capa de sua obra Fils, o termo "auto-ficção". Instauram-se na crítica, sobretudo a francesa, inúmeros e controversos debates a respeito do assunto.

Candido não discute a questão teórica de maneira explícita, mas o faz sutilmente ao sublinhar que os escritos selecionados eram da ordem do 
ficcional e/ou poético e, ainda, que tinham uma dupla e reversível leitura, isto é, seria possível lê-los como "recordação" - palavra que sugere a construção ficcional dos fatos pretéritos - ou como "obra criativa", configurando-se uma leitura de "dupla entrada", isto é, "simultânea, não alternativa" (p. 53). Em síntese, impossível ler tais textos ignorando-se a ficção e o ato estético. Tais reflexões revelam uma fina perspectiva crítica quanto à recepção de uma obra composta com traços do vivido, destacando num artigo, sem a pretensão confessa de se deter em problemas teóricos da "autobiografia", um modo de ler outras produções literárias dessa natureza.

Em linhas gerais, seu olhar centra-se no trabalho textual, tecido pelos autores citados, contemplando circunstâncias histórico-sociais e salientando que o ponto comum entre os três autores estaria na escolha de pedaços de suas vidas, nos quais a presença do Imaginário recai sobre certos traços afetivos peculiares ao passado, (re)elaborados graças ao trabalho verbal, ou seja, ao Simbólico. A leitura pretendida visa justamente tal ângulo, abordando, de forma específica, faces de Boitempo I, de Carlos Drummond de Andrade e de A idade do serrote, de Murilo Mendes, de acordo com o ensaio de Candido, pois, se o primeiro traz um "Narrador poético" (p. 55), o segundo talvez seja "o poeta mais radicalmente poeta da literatura brasileira, na medida em que praticamente nunca escreveu senão poesia, mesmo quando escrevia sob a aparência de prosa" (p. 57). Tal aproximação, ao lado de outras sugestões precisas do ensaísta, dá margem a relações líricas, bem como a interpretações ancoradas, sempre analogicamente, em aspectos teóricos da psicanálise. Sem as mencionar expressamente, Candido recorre a elas, permitindo ampliar os caminhos sintetizados por ele. É esse o intento a ser aqui perseguido.

Seja em Boitempo I ou em sua continuidade, Boitempo II, o eu poético busca algo perdido; dito de outro modo, busca o tempo e o espaço pretéritos da meninice e de parte da adolescência (seus 14 anos), vividos em Itabira, e Candido bem o assinala: é o adulto, escreve ele, que, por meio de um olhar distanciado, procura (re)compô-los. Também essa é a busca do narrador dos fragmentos de $A$ idade do serrote; contudo, esta parte da primeira infância, do momento inicial da vida: "Não me vi nascer, não me recordo de nada que se passou naquele tempo. Na verdade, nascemos $a$ posteriori".

Nessas obras, cria-se uma importante cadeia na qual apenas a (re)construção imaginária do eu lírico nos poemas e do narrador nos fragmentos conforma o conjunto de escritos. As lembranças, filtradas pelo presente, (re)compõem restos de determinados episódios de outrora e os transfigura literariamente. A posteriori, declara o narrador muriliano em relação a nosso nascimento. A posteriori poderia se sublinhar, a partir de Freud, para o nascimento do trabalho estético que implica Imaginário, memória e verbo, no adulto. 
"A posteriori" (nachträglich): no universo psicanalítico ${ }^{1}$, o termo tem dupla acepção, a de reelaborar os fatos pretéritos angustiantes e a de sublinhar que o tempo de agora desencadeia imagens pessoais anteriores e as contagia com impressões e eventos mais recentes, sinalizando que nunca se obtém nem o passado nem a verdade por inteiro. O presente interfere no tempo pretérito e este se desdobra no momento atual, (re)articulando-o e ressignificando o vivido. Nesse sentido, na (re)construção das lembranças - sempre lacunares - algo da ordem da ficção se instaura. No caso dos autores mineiros, somam-se à ficção mnêmica o dado lírico e a prosa poética. No entanto, além desses importantes aspectos, Candido focaliza dois pontos primordiais nas obras escolhidas que aqui ganham espaço: contar o vivido "sem amargura" em Boitempo I e a busca do "insólito" em A idade do serrote. Em ambos, além do poético, aflora um fino e saboroso humor.

\section{Drummond: cenas líricas do cotidiano}

Conhecedor do conjunto da obra de Drummond, nas primeiras linhas de seu artigo, Antonio Candido menciona a variação de estilo em Boitempo I (e Boitempo II) em relação a outros poemas de "memórias", assinalando a insistência do "veio autobiográfico sem amargura", evidenciado, em parte, pela volta da "piada", do "humor cotidiano", das "situações corriqueiras", características manifestas na seguinte citação de A astúcia da mímese, de José Guilherme Merquior, para quem o poeta de Itabira assumiria nas duas obras:

um giro deliberadamente brincalhão, como se (para dizê-lo na língua de Freud), o humor drummondiano, reconhecidamente tão "superdeterminado", tão equívoco ou polissêmico, emergisse desta vez alacremente unívoco, solto e gaio, sem as restrições mentais da emotividade ferida ao choque do mundo. (apud CANDIDO, 1989, p. 54)

Ora, Candido não escolhe Melquior ao acaso, menos ainda tal passagem que inclui Freud, para quem a memória está presente ao longo de sua obra, vinculada à subjetividade e à linguagem. Além disso, a noção citada ocorre especialmente quando o psicanalista trata dos sonhos com o

\footnotetext{
${ }^{1}$ Vale esclarecer que Freud vai elaborando a questão ao longo de sua obra. Cf. A história do movimento psicanalítico. (FREUD, 1914 /2006). Em linhas gerais, a questão da temporalidade psíquica aponta que, para o sujeito, "seu passado vai se construindo em função de um futuro ou de um projeto" (ROUDINESCO, E. e PLON, M., 1997, p. 56).
} 
intento de esclarecer que superdeterminação ou sobredeterminação é um efeito da condensação, um dos processos oníricos, cuja função, ao lado do deslocamento e da figurabilidade, é a de encerrar múltiplas interpretações e, graças a esse elemento sobredeterminado, dá a aspectos de menor importância maior valor, sugerindo, assim, a força da censura na cena onírica.

Por sua vez, Merquior, continuando o trecho citado, escolhe o poema "Queda" para leitura mais atenta; logo, retomamos tal poema para compreender melhor a questão. Nele, Drummond coloca uma donzela no alto de um balcão, contemplando a cena de um cavaleiro em pleno século XX, condensando duas épocas. Contudo, ao invés de manter a desejada postura altiva para seus "belos olhos" femininos, o moço sofre uma prosaica queda, confessando, no último verso, ter sofrido "uma total humilhação". À ironia do tombo, acresce-se a falta de sincronia do tempo, peculiar à cidade pequena onde todos se conhecem, instaurando a questão do eu lírico:

\section{Por que, no século 20, logo a este acontecer? Naquela rua?}

(DRUMMOND, 1973, p. 86)

Um jogo amoroso medieval, em pleno século 20(?!), vem marcado pelo número arábico, corrente à época atual, que desloca o algarismo romano, clássico na representação dos séculos, assinalando a anacronia dos costumes, geradora da humilhação final e descabida, pois em descompasso com o tempo. Constrói-se a crítica irônica em relação ao provincianismo e o riso "grácil" aflora sem acidez, exatamente por tal descompasso.

Dentre vários textos brincalhões, tais como "Queda", é possível mencionar como exemplos "Diabo na escada", "Os excêntricos" e o poema narrativo "Suum cuique tribuere", que revela um efeito fundamental de censura, desde a ironia do título latino, permitindo o entendimento de "dar a cada um o que é seu" e assinalando também o olhar do adulto para o pequeno e distante universo de Itabira, conforme se lê ao longo dos versos:

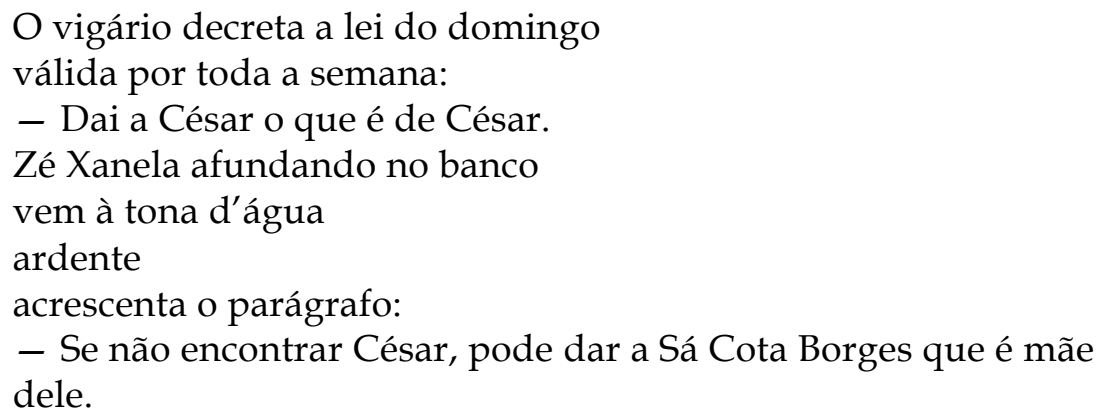


Do ponto de vista da psicanálise, a criação dos poemas citados, nos quais o ludismo se insinua, parece obedecer ao princípio do prazer, cuja função é evitar o desprazer, e em Boitempo I o desprazer de algumas recordações de outrora. Especificamente, em "Suum cuique tribuere", o eu lírico se vale do brincar infantil como forma de prazer na designação "Zé Xanela", evocando lúdicas associações verbais: Zé Janela, Zé Canela, Zé Chinela etc., além da deliciosa ambiguidade da diferença de níveis culturais, que ironiza a pregação do vigário, tanto pelo título em latim, incompreensível aos fiéis, como pela menção ao imperador César para um público simples, que desconhece, em geral, a história de Roma, porém parece reconhecer a de seu cotidiano: a história comum do filho de Sá Cota Borges. O humor manifesta-se graças ao deslocamento de sentido do nome próprio, questionando o discurso do vigário, expondo sua inadequação e descompasso no que concerne ao nível de informação histórica de seus ouvintes.

O jogo de palavras apoia-se no equívoco e na brevidade do poema, fulcral para desencadear o riso a serviço do princípio do prazer e do desejo do eu lírico, atuantes na transgressão da lei e da censura, rompidas por meio da introdução do nonsense do recado de Zé Xanela. Tal figura emerge do banco e de uma provável "bebedeira" de "aguardente" - palavra expressamente pontuada por sua divisão em dois versos água/ ardente, elaborados por um eu poético crítico e articulador do presente. Ao despertar, Zé Xanela busca cumprir, de algum modo, a imperativa lei cristã e, sem o saber, a descontrói, ao trocar as personagens e apequenar o César romano - a atitude, além de satirizar o pároco, dá voz aos fiéis que, análogos a Zé Xanela, não entendem a prédica, tornando-a ineficaz.

$\mathrm{O}$ eu lírico cria essa figura, que desvia a língua no próprio interior da língua, se recuperarmos considerações de Roland Barthes, causando um "estrago" benéfico à comunicação (BARTHES, 1980, p. 19). Ao tratar do nonsense, Freud menciona a dualidade "desconcerto-esclarecimento" (FREUD, 1896 /2006, p. 24) que o termo comporta e a possibilidade de sua transformação, às vezes, em chiste. De certo modo, Drummond vai nessa trilha - e Murilo ainda mais intensamente, conforme se verá -, pois trabalha com a transgressão por via do humor, "dom precioso e raro" (FREUD, 1927 /2010, p. 330) que faz o homem rir de si próprio, encarar, entre outros aspectos, a dor, o mal-estar, a finitude e, particularmente no poema, o papel do humor seria o de desfazer um poder, totalmente deslocado do próprio ensinamento cristão, em uma pequena comunidade na qual o padre é um dos representantes da lei.

Em síntese, o eu poético realiza seu desejo de virar o jogo, ridicularizando um poder que inferiorizava os demais, valendo-se do 
princípio do prazer e do próprio mecanismo do humor, que precisa da "cena social" para ser bem sucedido. Além dos fiéis, os leitores pactuam com tal cena, saboreando um duplo reconhecimento: a grandeza de César romano e seu apequenamento, efetuado pela palavra transgressora que desencadeia o riso e reduz o prestígio do padre para instaurar uma forma de "contrapoder" (BIRMAN, 2010, p. 188).

\title{
Fragmentos do vivido drummoniano
}

Destacam-se aqui os termos: casos, cenas, emoções da infância (CANDIDO, op. cit., p. 54); ou seja, fragmentos do viver que retornam como traços pretéritos lacunares, demandando ressignificação. Aliás, se não há em Boitempo I a insistência da sobredeterminação, tais traços também permitem evocar a "língua de Freud", pois o trabalho mnêmico propicia confluências entre o poeta e o psicanalista. Não por acaso, "(In) Memória" abre a obra do primeiro, preparando o leitor para os pedaços de vida agora concretizados pelo verbo - que se tentará ilusória e paradoxalmente enfeixar, com lucidez, evitando a perda da memória da existência. Parece claro ao eu lírico que ficam lacunas, restos de lembranças, condensados no vocábulo "resumo":

\author{
De cacos, de buracos \\ de hiatos e de vácuos \\ de elipses, psius \\ faz-se, desfaz-se, faz-se \\ uma incorpórea face, \\ resumo do existido
}

(DRUMMOND, 1973, p. 7)

A psicanálise sustenta que as lembranças jamais ressurgem como outrora vividas, mas reaparecem nas sensações angustiantes não resolvidas e em impressões, experiências e acontecimentos mais recentes, desencadeadores de imagens, cenas e episódios pretéritos, nem sempre relacionados explicitamente. Em linhas gerais, os poemas dramatizam liricamente o acordar das lembranças, comportando estilhaços da existência em unidades formais, cenas independentes, mas, paralelamente, partilham um fio comum - a (re)construção do vivido - que autoriza a leitura da obra em seu conjunto. O mesmo se constatará nos fragmentos de A idade do serrote, espécie de relances de inúmeras lembranças. Com acerto, Candido assinala que o intuito 'autobiográfico', em Boitempo I, não vem marcado pela "auto-análise", "dúvida", "inquietude" ou "sentimento de culpa", se pensarmos na virtual totalidade da obra e que o poeta se inclui "deliberadamente na trama do mundo como parte do espetáculo" que se configura em alguns poemas de Lição de coisas (1989, p. 55). 
Candido assevera, com relevância, que o poeta se vê de "fora para dentro". Em direção distinta, é possível aventar que esse "dar a ver" para o mundo (o Outro) também constitui uma forma de ele ser olhado, de se mostrar e mostrar sua criação, tornando-se objeto do olhar alheio, o que o leva a privar-se do próprio, para que sua arte desvele-se e exista. Dar visibilidade a seus versos permite ao poeta persistir no tempo, porém, paralelamente, ele deve aceitar os diferentes sentidos alcançados pela recepção de sua obra. E, aqui, volta-se a Candido, reiterando e ampliando a ciranda interpretativa de seu ensaio: o trabalho pessoal do eu lírico (que já se fez com aspectos de inúmeros saberes, nem sempre conscientes) tornase cultural e, pode-se acrescentar, o poeta abdica de seu olhar em nome de uma função maior: a de legar a todos sua lírica.

Nessa direção, cabe reler "Herança", poema no qual o doloroso sentimento de perda e a conhecida contraposição drumondiana, a seca ironia (que, embora não prevaleça no conjunto de Boitempo I, não deixa de aflorar), não só evocam muito da "Confidência Itabirana", de Alguma Poesia (1930), mas reconstituem igualmente o universo econômico-social de outrora, algo do "eu" e dos "outros":

\author{
De mil datas minerais \\ com engenhos de socar \\ de lavras lavras e mais lavras \\ e sesmarias \\ de bestas e vacas e novilhas \\ de terras de semeadura \\ de café em cereja (quantos alqueires?) \\ de prata em obras (quantas oitavas?) \\ de escravos, de escravas e de crias \\ de ações da Companhia de Navegação do Alto Paraguai \\ da aurifúlgida comenda no baú \\ enterrado no poço da memória restou, talvez? este pigarro.
}

(DRUMMOND, 1973, p. 63)

Aqui, a construção é semelhante aos textos já citados. Predominam as frases nominais, pois os bens financeiros, indicativos (alguns quase incontáveis) do patrimônio de antigamente - que se estendem de terras, gado e minerais a seres humanos, de ações à honraria social - não passam hoje de mera enumeração mnêmica. Resta ao eu lírico um verbo ("enterrar") no particípio passado, que rompe inexoravelmente a lista de bens e se converte em parte da metáfora "poço da memória", que, por sua vez, se desfaz facilmente, pois a memória não é um grande buraco, nem um reservatório para resguardar acontecimentos e emoções.

Vale reiterar que, em psicanálise, a memória escapa ao senso comum, ao estabelecer elos com o desejo, o inconsciente, os afetos, as experiências e a linguagem. Segundo Freud, entra aí o tempo do 
inconsciente que obedece a uma lógica própria, diversa do tempo cronológico, e atua na (re)construção das lembranças, (re)articulando e (re)criando traços do passado, no presente. Conforme se viu, esse processo ocorre "a posteriori" ("nachträglich", FREUD, 1914 /2006), ou seja, as marcas mnêmicas, inscritas desde a infância, podem ser ressignificadas em outro momento da vida, contagiadas por fantasias, sonhos e lembranças ulteriores. Guardadas as devidas diferenças, se, na análise freudiana, é possível encontrar novos nexos e interpretações do passado a cada fala, na literatura se obtém resultados semelhantes a cada (re)leitura. Contudo, no primeiro caso, nem sempre tal processo se realiza, pois, muitas vezes, as marcas mnêmicas retornam sob a forma de repetição, permanecendo irrepresentáveis e fora do campo da linguagem, embora interfiram, com intensidade, no presente.

Nos poemas de Boitempo I, a repetição não é um sintoma, mas um recurso literário. Em "Herança", ela atua nas lembranças, ao longo dos onze versos, insistindo na perda dos bens de outrora como algo incessante, insinuando a dor sem o explicitar e desvelando o passado em função de sua contraposição, a saber, o mísero, duvidoso e diminuto fecho que encerra o último verso: "este pigarro". Ora, do ponto de vista cultural, o resto que fica vale bem mais do que o referido pigarro. Ao recobrar fatos, que podem ser comprovados pela história de Itabira, o eu lírico não só evidencia uma nítida recordação de sua cidade, integrada à coletiva, como, da perspectiva psicanalítica, revela se sobrepor ao esquecimento que o desprazer das perdas poderia provocar. O inventário dos bens perdidos, espécie de registro poético, destaca não apenas o respeito ao princípio de realidade, mas também a maestria de dar forma lírica à dor; ou seja, verbalizá-la de algum modo, embora com rasgos irônicos. À primeira vista, só lhe resta o pigarro, o som surdo que dá voz ao corpo, resultante de uma irritação da garganta, uma mucosidade de que se quer livrar.

No entanto, se tal viscosidade causa mal estar, ela é igualmente defesa do organismo. E a maior defesa do eu lírico é a reelaboração da lembrança das perdas por meio da poesia. Ele não deixa de inserir, no verso final, o pequeno advérbio "talvez?" A dúvida constante de grande parte da obra de Drummond, o conflito peculiar ao humano que persiste. O que pesaria mais? Impõe-se, então, a pergunta: e suas perdas? Sobretudo, porque elas são também as dos habitantes de sua cidade. Mas, é preciso reafirmar que resta, ao sujeito lírico, a criação - legado maior e ainda prazeroso, oferecido aos itabiranos e a seus leitores. Ele sabe dar forma poética às dores e aos fantasmas, sabe reelaborar as perdas da existência de qualquer sujeito frente ao tempo, à história e à finitude. $\mathrm{O}$ poeta dá a ver ao mundo o prazer das imagens literárias de Boitempo I. E, nesse momento, reencontra-se Antonio Candido e sua feliz interpretação: 
Em Boitempo e Menino antigo a estilização literária é aplicada para narrar a existência do eu no mundo: particularizadora, de um lado, na medida em que destaca o indivíduo e seus casos; mas, de outro, generalizadora, porque é simultaneamente descrição de lugar e biografia de grupo. Os fatos e sentimentos, as impressões e ambientes, que são o ponto de partida da elaboração literária, pesam com maior impureza do que na obra lírica anterior; e, como acontece nos livros de memórias pessoais, a elaboração da forma não chega a dispensar o sentimento vivo do objeto, ponto de partida, porque o escritor quer justamente pô-lo na luz da ribalta, embora poeticamente transfigurado. (CANDIDO, op. cit., p. 56)

\title{
Fragmentos do vivido muriliano
}

\author{
Segundo Candido, se
}

Itabira de Boitempo é uma presença física definida, embora enroupada de magia [...], a Juiz de Fora de $A$ idade do serrote é tonalidade quase fantasmal num lugar permeado de sonho. As pessoas, os animais, as coisas, as cenas se revelam sempre múltiplas - são e não são. (Idem, p. 57)

Não bastasse tal afirmação, o ensaísta complementa que elas "extravasam os limites e o instante", isto é, o tempo obedece a uma lógica diversa. O universo compreendido nos fragmentos (ou crônicas, ou episódios ou "capítulos(?)") da obra trata "loucura e milagre" como "normais". Literal e precisamente, Antonio Candido resume que o

\begin{abstract}
Narrador não apenas transfigura o dado comum, como algo tocado pelo cunho excepcional, mas introduz propriamente dito sob a forma de excentricidade, aberração da norma, loucura [...] o comum é visto como extraordinário; o extraordinário é visto como se fosse comum (p. 57)
\end{abstract}

Em uma palavra, Murilo Mendes, seria um "grande estrategista do insólito e da transcendência" (p. 57), sem ignorar o dado poético de sua prosa. Essas observações se abrem à leitura que leva em conta aspectos da psicanálise, pois o dado psíquico aí se manifesta; Murilo se vale da outra lógica, a do inconsciente, ao compor seus textos, e Candido o percebe bem qualificando-o, vale sublinhar, de "grande estrategista do insólito". Os termos "fantasmal", "sonho", "insólito" não foram selecionados pelo crítico ao acaso. Conhecedor do surrealismo e de Freud, o autor de $A$ idade do serrote, tal como o psicanalista, emprega a já mencionada expressão $a$ posteriori (nachträglich), para dar conta de seu nascimento, podendo-se estendê-la à (re)construção dos acontecimentos mnêmicos, os quais se elaboram sem ordem cronológica, mas procurando dar a impressão de se inscreverem no instante em que afloram, ou seja, estilhaços do vivido 
parecem retornar desordenadamente, misturando experiências pessoais e acontecimentos culturais. Aliás, inúmeros acontecimentos culturais.

Todos ganham, entretanto, forma estética. Lirismo e humor em maior ou menor proporção mesclam-se e o narrador vai compondo fragmentos ou "unidades autônomas", "à maneira de crônicas", no dizer do ensaísta, embora possam ser lidas como conjunto de cenas do passado que articulam relances da vida do narrador. Em comum, têm, ainda, nomes de personagens como títulos e perseguem um eixo: a construção das lembranças, ora poéticas, ora irônicas, ora "insólitas", ora mescladas por tais aspectos. Contudo, aqui, as terceiras serão o foco maior, já que em seu ensaio, Antonio Candido aponta com justeza a presença do "uso sistemático do insólito" (p. 58), tocando o "dado comum" e lhe imprimindo outro nexo.

Desde o princípio de $A$ idade do serrote, em "Origem, memória, contacto, iniciação", já se anunciam textos semelhantes a jorros mnêmicos, mas envolvidos por certa unidade de sentido, conferida pelo fino trabalho verbal que comporta diferentes afetos. Aos pais, primeiros amores, babás, professores, artistas, a admiração e o gesto terno, às primeiras musas eróticas, o olhar tão devorador quanto ao lançado aos primeiros livros ou às primeiras atrizes, e aos vários personagens da família e da cidade a percepção do traço estranho, porém revelador de algo cativante que lhe abre um universo inesperado, só traduzido graças às rupturas da palavra, ao que Candido chama de "insólito linguístico" (p. 59). E, nele, o leitor pode pressentir alguma desorientação, perguntando-se: esse insólito provém das pessoas conhecidas em Juiz de Fora ou do discurso que as constrói? Ou pouco interessa quem vem primeiro, pois ambos não se separam? O narrador se expõe de pronto:

\footnotetext{
Nasci coisando, nasci com a música. Recordo-me perfeitamente de ouvir nosso Orfeu número I, flauteando na casa de meu pai, de Titiá e de Sinhá Leonor, tendo eu três anos de idade; Mamãe Zezé pianolando e cantando, mais tarde soube, árias de Porpola e Caldara. (MENDES, 2014, p. 17)
}

Ora, o leitor encontra explicitamente esse modo de escolher o verbo e seu tempo, o gerúndio ("coisando"), e a acentuação deslocada ("titiá") num fragmento ulterior, "Tio Chicó", apelido de tio Francisco, caracterizado como "um doido manso" que costumava trocar nomes e títulos das pessoas e, liricamente, "rosava as dálias, daliava os goivos, canarizava os sabiás e assim por diante" (2014, p. 46), além de entrever dentro de seu quarto (evocação a Voyage autour de ma chambre de Xavier de Maïstre?) possibilidades de invenções que não encontrava fora dele. E o jogo linguístico de Chicó (ou do sobrinho para descrever a cena com o Tio Chicó) vai se destacar em muitos episódios da obra, unido ao uso de termos estrangeiros e de atmosferas inusitadas. 
Uma delas pode ser observada em "Amanajós". O texto principia com "O ar dá tiros", imagem ímpar que reúne substantivos de universos diferentes (ar e tiro), criando uma expectativa intrigante, preparadora da entrada do transgressor das famílias burguesas de Juiz de Fora: o bêbado Amanajós. Literalmente, "grandão, sinistro, olhar de capa e espada, nu da cintura para cima [...] assemelhando-se ao homem do quadro "Le cerveau de l'enfant do Primeiro de Chirico" (Idem, p. 25). Há em sua caracterização um misto dos povos indígenas brasileiros e do europeu, pois, seu nome remete ao de uma tribo, oriunda do baixo Tocantins, e, paralelamente, $\mathrm{o}$ olhar evoca o herói dos romances de capa espada, que à coragem une diversão com bebidas e mulheres e, ainda, o narrador adulto incorpora a associação erudita e europeizante do quadro de Chirico (de sua fase metafísica), cujo estranhamento desperta o interesse de alguns surrealistas, tendo sido, inclusive, adquirido por Breton.

A figura de um homem com o dorso nu, em frente a uma mesa, sobre a qual está depositado um livro, comporta certa estranheza, pois se instaura um jogo entre o mostrar e o velar que inquieta: o livro fechado (ainda a ser aberto ou indicativo de leitura encerrada?), o dorso alvo que contém partes sombreadas e cuja brancura predomina em meio a cores (negro, cinza, vermelho, azul), o bigode grande e os cílios negros sobre os olhos, que podem ser interpretados como completamente ou meio cerrados. E, mais, a parte inferior do corpo é oculta pela mesa e um dos braços coberto pela cortina, ou seja, nada do que se vê é inteiro, há sempre uma parte encoberta ou sugestiva de um lado não visível. O próprio título do quadro comporta ambiguidade, o cérebro ou a mente ("cerveau") é de um menino, mas se visualiza um homem. Parece ser esse paradoxo que fascina o narrador e sustenta a comparação, ao expor a divisão do sujeito, pois Amanajós é a figura sedutora entre o bem e o mal, que pertence a elite de Juiz de Fora, "genro do Comendador F..." - cujo nome não se divulga, preservando-se ironicamente o respeito social do título do sogro, porém Amanajós ignora as normas de tal classe. É advogado, devendo, portanto, obediência às leis, mas as transgride; propaga a boemia entre os jovens, desarranja a ordem pública, é despachado pelo governo para o Acre, mas não se emenda, preferindo a prisão e a morte a abdicar da bebida.

Em ponto menor, "arrabiato fuorilegge encharcado de caninha" ( $\mathrm{p}$. 25), o italiano e o diminutivo que denomina nossa bebida mais popular, insinuam, de novo, sua divisão enquanto sujeito e adentram o texto, paradoxalmente, como se fossem uma só língua, sugerindo inteireza. Contudo, o leitor sente a ruptura linguística e ela cria certa ambiguidade, antecipadora da oscilação entre a grandeza de uma "voz atenorada" e o apequenamento de ser chamado "o tenor da cachaça", que reúne, na expressão, o erudito latim "tenere" e o português da "cachaça", já que o vocábulo compreende traços da língua ibérica "cachaza" e se vincula à primeira espuma da produção colonial do nosso açúcar. Amanajós é 
também o introdutor da ideia desordenadora do demoníaco, admirado, pois ainda melhor do que o contexto histórico do narrador-adolescente, determinado pelo fascismo e pela bomba atômica.

Desde as primeiras linhas, a personagem se configura como "sinistro" 2 e tal adjetivo se estenderá ao fragmento seguinte, "Marruzko", dedicado ao leão que inicia o narrador no mundo particular dos bichos e lhe revela literalmente seu temor não dos seres, mas da palavra. $O$ fato de o leão não urrar, leva o narrador a declarar respeito por "sua pessoa" e, nesse sentido, a tecer outras considerações quase humanas sobre o animal, até com certa ternura, confessando que o medo vinha de outro lugar, ou seja, da palavra. Afirma ele: "O nome do leão era Marruzko. Esses dois erres, com zê azedo e o ká cortante, mais o urro do u no centro, formavam um composto que me aterrorizava". Essas sensações despertadas pelos fonemas não seriam uma homenagem a Rimbaud e seu "Voyelles"? Enfim, o motivo do "terror" (que ocultaria o fascínio) é da ordem do verbo. E, ainda, em linhas gerais, os textos de $A$ idade do serrote encenam a palavra, inventam, desviam e deslocam expressões sempre em busca de outra lógica, sugerindo o insistente desejo do narrador pela elaboração verbal.

Em tal viés e não por acaso, os textos "Amanajós" e "Marruzko", metonimicamente, se seguem e tocam na organização do livro. À primeira vista, associam-se pela "insólita notícia" que o segundo fragmento divulga: o maior boêmio de Juiz de Fora entra de madrugada na jaula do leão que dormia e, pela manhã, quem é encontrado dormindo, "o sono dos bemaventurados", é o advogado, enquanto o animal "espaventoso", desperto, lhe faz companhia. Interessa sublinhar os adjetivos que configuram o leão: "velho, desdentado, amnésico, vegetariano". À semelhança do transgressivo Amanajós, ele também rechaça as normas de sua espécie e não come carne. Além disso, sofre de amnésia, pressupondo que teria lembranças a esquecer e, nesse jogo associativo, o narrador se pergunta se "os seres mais inumanos" teriam alguma ligação com a ternura, "não só o leão ou o tigre", mas "o carrasco, o ditador, o alto executor dos campos de concentração, o artífice da bomba" (p. 31). O trecho retoma o contexto já assinalado no fragmento "Amanajós", configurando-se muito mais demoníaco do que os desarranjos realizados pelo bêbado, que assusta a cidade "clarinando nomes feios" ou se mascarando fora do carnaval.

No entanto, o insólito da cena de Marruzko e do advogado evoca um aspecto mais perturbador, a saber, a perversão das figuras humanas citadas, responsáveis pelos atos finais do texto antecedente. O narrador vai graduando os casos de estranhamento. Ao relatar a entrada de Amanajós na jaula, com o leão adormecido, há uma citação de "Booz endormi » (La legende des siècles), de Victor Hugo, segundo a qual, já havia passado "l'heure tranquille où les lions vont boire. Tout reposait dans Ur et dans

2 Curiosamente, a palavra é empregada em espanhol como uma das traduções do "Unheimich" de Freud: "lo siniestro". 
Jérimadeth» (p. 30). Há uma espécie de troca de papéis: primeiro, de escritos, pois o de Hugo rompe o que lemos e os versos franceses substituem a prosa em português, depois, troca do momento de beber das personagens, pois a hora tranquila de o leão beber se opõe ao fim (ou auge) da bebedeira de Amanajós, que acaba caído na jaula. Porém, os dois deslocamentos assinalados ocultam outro, vinculado ao sabor pelo estranhamento verbal que se repete ao longo dos episódios e se encontra no nome das cidades de Hugo. Enquanto a existência de Ur é comprovada no mundo bíblico por arqueólogos e historiadores, Jérimadeth não. Parte da crítica francesa atribui tal invenção a um jogo verbal do autor (para rimar com o verso "Brillait à l'occident, et Ruth se demandait »), pois se pode ler "J'ai il peut rime à dait »; outra parte considera que houve uma feliz busca de sonoridade para contemplar a língua hebraica, enfocando as relações com a "cor local" e "temporal" (p. 107). ${ }^{3}$

Cabe aqui considerar dois enfoques: o de Murilo e o de Candido. O episódio e o ensaio demonstram, em ponto menor, o que se observa no conjunto de $A$ idade do serrote, voltada sempre para o efeito da palavra e, por extensão, da literatura. Em "Marruzko", a entrada de Hugo propicia mais evocações poéticas, a de Mario de Sá Carneiro e de Teixeira de Pascoaes (agradáveis ou de "indúbia sugestão" pelo emprego impróprio de certo adjetivo), chegando-se a um "fecho leonino" pelo empréstimo de Jean Arp, artista reverenciado pelo narrador, e, de novo, a língua francesa desloca a portuguesa: "Par conséquent [...] Le lion est un diamante" (p. 32). Ora, já se está no oitavo fragmento da obra e a singularização ou "estranhamento artístico" (no sentido de Chklóvski ${ }^{4}$ ), passa a ser cada vez mais familiar, viabilizando a perspectiva de Candido, pois, "o leitor tem a impressão de estar sempre no mesmo contínuo linguístico" (p. 58). “[...] o insólito linguístico parece normal e, ao mesmo tempo, cria uma originalidade rara e inesperada, que encaminha a frase para um campo mais largo de significado [...]" (p. 59). O crítico aponta também o caso de palavras "ajeitadas à portuguesa", enumerando várias frases e expressões que se desdobram em outros fragmentos do livro.

Interessa essa duplicidade do familiar e do estranho porque ela sustenta várias figuras murilianas, sendo que um aspecto engendra o outro e vice-versa. Primo Alfredo, por exemplo, descreve um dentista e professor que passava as férias em Juiz de Fora, tratando-se do primeiro intelectual

\footnotetext{
3 Sobre o assunto, afirma Parisot: "Ce nom de ville a été inventé par Hugo pour rimer avec se demandait; se lire "J'ai il peut rime à dait »». In: PARISOT, Henri (éd.). Avant-propos à Victor Hugo, ... La Bouche d'ombre. Paris: Gallimard, 1943, p. 15. Para outra posição, v. PÉGUY, Charles. "Victor-Marie, comte Hugo». In: Les Cahiers de la Quinzaine, XIIe série, 1 er cahier, octobre 1910.

${ }^{4}$ Para esse teórico, "o objetivo da arte é dar sensação do objeto como visão e não como reconhecimento; o procedimento da arte é o procedimento da singularização dos objeto e procedimento que consiste em obscurecer a forma, aumentar a dificuldade e a duração da percepção". CHKLOVSKI, V. "A arte como procedimento". In: Teoria da literatura. Formalistas russos. Porto Alegre: Ed. Globo, 1971, p. 45.
} 
que o narrador diz ter conhecido de perto. O jovem admira-o e sua atenção captura os níveis de estranhamento da personagem, a começar por uma palavra que lhe parece "insólita àquela época: proletariado." O primo apresenta-lhe, ainda, Silvio Romero e discute com seu pai questões religiosas. E, mais, infringe regras recorrendo à ironia do discurso, algo que insiste na elaboração escrita do narrador-adulto, impondo forte crítica à igreja, à política e à burguesia da cidade. Alfredo menciona, por exemplo, que a única originalidade de Monsenhor G... era "palitar os dentes fora das refeições", ou, ao saber que voltara o hábito de jantar à luz de velas, "dos tempos imperiais", propõe que deveriam instaurar outro rito, o de "descomer em grupo à luz de velas". Sem dúvida, o intento é chocar, romper ou transgredir o contexto burguês da cidade, assemelhando-se a Amanajós e dele se diferenciando pelo método: é via discurso que o primo reinventa o mundo (ou o narrador reinventa o primo?).

\section{O estranhamento das personagens femininas}

Não só as personagens masculinas se compõem com traços insólitos, algumas das femininas também. Aliás, no ano da publicação de $A$ idade do serrote, em texto para Correio da manhã, Drummond já afirmava: "Só as mulheres formam um universo poderoso, gravado em poucas linhas, na variedade de graças e grotesco [...]" (2014, p. 167). Pode-se acrescentar que, como nos episódios já referidos, tais aspectos se aliam ao humor. Duas viúvas, Dona Coló e Dona Custódia, são exemplares de tal relação. A primeira cheira a "galinha molhada", tem fios de barba, "voz de taquara rachada", é invasiva em conversas alheias e libidinosa com o narradormenino, que a repele enojado, opondo-a às prazerosas carícias da fogosa vizinha Lili de Oliveira. Coló desperta no jovem a questão do lugar dos "colós" e das "colós" no outro mundo, já que Deus não os despacharia para o inferno porque o ajudam a sublinhar sua incessante "e polida paciência".

Já a segunda tem "seios anônimos", "pernas sem caráter", estrábica, de sorriso "também estrábico", com buço "ameaçando transformar-se em bigodes", isto é, semelhante a Coló perde o perfil feminino e, comparada a uma máscara, não necessitava de nenhuma no carnaval, pois "dispunha da própria cara". Variante das figuras de James Ensor, ao lado dos mascarados, o escrito sobre Custódia retoma o "a posteriori" freudiano tão importante para o trabalho mnêmico realizado na obra - , uma vez que o diálogo com a pintor belga destaca o olhar do narrador adulto, que não conhecia Ensor no tempo de menino. "Antropófago", aproxima a mulher, pertencente à pequena comunidade, a máscaras expressionistas, oriundas da arte europeia, para denunciar a "hipocrisia dos rostos", além do gosto duvidoso (conforme a descrição de sua sala) e excessos exibicionistas, especialmente a homenagem, feita por ela ao marido-morto, e descoberta 
no meio da sopa do jantar, pois do fundo do prato emerge a "cabeça do coronel Pedroso e seus bigodes enormes".

Para o narrador, Dona Custódia lhe permite perceber o "lado ridículo, o loplop cômico da pessoa humana", cabendo esclarecer que o termo "loplop" recobra a figura híbrida de um homem com cabeça de pássaro, apresentada no romance-colagem A mulher 100 cabeças, de Max Ernst, e sugestiva tanto de antigas criações míticas, como do diálogo com esse pintor e poeta, ligado ao surrealismo. Nas duas personagens femininas, aflora o traço grotesco de parte da burguesia da cidade, ilustrando igualmente os "tipos bizarros" que o jovem conheceria ao longo da vida. No entanto, em outro episódio, o de "Asta Nielsen", surge a primeira revelação "do loplop feminino", valorizado pela atriz dinamarquesa. Ao contrário das viúvas, ela propaga a reduplicação de cabeças (cem /100) em suas interpretações, graças ao jogo imagético do cinema.

E "Asta Nielson" não está só em tal contraposição. Há personagens femininas que se constituem de modo paradoxal, comportando estranheza e fascínio. É o caso de "Carmem", a prima qualificada como uma "górgone" em "escala reduzida", provocando "atração e repulsa" e, exercendo as funções masculina e feminina. Tal conformação assinala sua duplicidade, intensificada pelo emprego do termo "evadâmica" (Eva e Adão, mal e bem...). Além de seu nome evocar a cigana homônima de Merimée e/ ou Bizet, caracterizando-a como mulher fatal, a moça comporta traços da Medusa, pois é capaz de paralisar o parceiro e, ao mesmo tempo, despertar-lhe o desejo de assassiná-la. Em jogo, mais uma vez, o desejo do narrador com suas contradições, deslocamentos e fantasmas.

Portadora de dentes poderosos ou, com todas as letras, de "uma formidável dentadura num background de testa, olhos e cabelos", Carmem a tudo morde e domina. Sem ser o tipo do jovem, opõe-se a Dona Coló e a Dona Custódia, já que não cria, como a primeira, sentimento de "nojo" e alívio ao narrador quando falece; nem como a segunda, a desconfortável impressão de morte da beleza, pois "antídoto das mulheres bonitas". Oposta à pulsão de morte que envolve as viúvas, a prima encarna a de vida e, por meio dos dentes que mordem, sugere a sensualidade expressa na metáfora "o sol erótico, uma janela sobre a vida", enquanto o cheiro de seu corpo coloca o adolescente "frente à matéria viva, imediata".

Não só em "Carmem", o dado erótico se mescla ao insólito, pois, na formação do narrador, outras mulheres são delineadas paradoxalmente: mistos de enigma e sedução. "Abigail", por exemplo, "vamp honesta", empurra-o para modernidade, abrindo-lhe horizontes poéticos, por uma ideia, segundo a qual "um simples manequim de costureira" seria "mais belo e sugestivo que qualquer estátua grega". Adulto, ele observa que a moça, sem o saber, retoma Huysmans, índice das relações literárias que o perseguem. Contudo, interessa sublinhar o "acontecimento insólito", 
conferido a Abigail, desvelando a "miséria" da condição humana, e justificando o argumento de Antonio Candido, para quem um dos aspectos de $A$ idade do serrote está no "movimento pendular", no qual o comum é visto como extraordinário e este como comum (CANDIDO, 1989, p. 57), ampliando-se o alcance da criação estética de Murilo.

Literalmente, Abigail é protagonista de "um acontecimento insólito" na vida do narrador, pois ela começa a sofrer desmaios, tonturas e vertigens e não se descobre o motivo, até se esclarecer que expelira uma "enorme solitária" ("setenta metros de comprimento, diziam"). Angustiado, o narrador se impressiona, garantindo que "o erotismo parecia anulado para sempre"; porém, a afirmação se desfaz quando a moça se restabelece, encorpa e ele restaura sua imagem pela metáfora "grande rosa aberta". No fim, ela acaba se casando, deixando o jovem desconsolado, a ponto de só se recuperar quando sabe que ela "era infeliz com o marido", ou seja, há um sabor de vingança que sublinha outra forma de manifestar seu olhar, não apenas irônico, mas contaminado por certa maldade.

Contudo, é a irmã de Abigail, Hortência, quem traz à tona uma das mais intensas sensações de estranhamento, pois, desde pequena se alienara do convívio de todos, trancando-se em um quarto do sobrado em que vivia. O Imaginário da coletividade cria várias versões para seu isolamento. $\mathrm{O}$ narrador experimenta enorme curiosidade em vê-la, todavia, só consegue entrever "um raio oblíquo de seu rosto", quando ela perde os pais e vai morar com Abigail. Sua saída é marcada por uma atmosfera fantasmática, embora, textualmente, não houvesse "vento" uivando, algo que poderia evocar contos de suspense ou terror. Ela sai, à noite, envolta em "véus negros viuvais" em um automóvel com cortinas fechadas, mantendo o mistério. Tempos depois, o narrador relata compreender o significado de Hortência para si mesmo: ela teria sido a "anunciadora" de personagens de Dostoiéveski e Kafka. Mais uma vez, em Murilo, a literatura se sobrepõe ao cotidiano, ainda que rompido pelo enigma da moça. Os dois autores citados são mestres em criar seres atormentados; no primeiro, a angústia enclausura-os, no segundo, o encerramento é literal, uma vez que as personagens se debatem num contexto social sem saída ou explicações. A lógica, análoga a do inconsciente, é outra. A angústia, ou algum afeto psíquico que domina Hortência, poderia ser pensada como parte de outro campo do saber, a medicina ou a psicanálise, por exemplo; no entanto, cabe à literatura - e por extensão àrecoirdar cultura - tal papel.

Assim, ainda para entender a função da moça, o narrador dedica-lhe um parágrafo, o último do episódio, vinculando-a a lembranças culturais. Ela seria, entre várias comparações, a "musa secreta da pré-história, a noiva impossível do bisonte de Altamira" ou a "irmã gêmea do Máscara de Ferro ou de Hölderlin-Scardanelli trancado em sua torre de Tubingue", 
ou, ainda "uma das confidentes de Julien Green e de Lúcio Cardoso". Essas associações comportam sempre algo inquietante, a pintura rupreste paleolítica do bisonte destaca não só o espaço fechado da caverna em que se encontra, como contém belas e estranhas figuras de animais, intrigando o homem contemporâneo pela arte inusitada e expressiva da época. Já Green é marcado pela dualidade e fantasmas que determinam sua vida, expostos ou censurados em sua obra (Journal), e não se pode ignorar que Lúcio Cardoso, em Crônica da casa assassinada, constrói uma personagem, pouco aceita por seu meio, que se isola em seu quarto, no interior de uma casa, gerida por preconceitos, mortes e fantasmas de membros da família, ao longo dos anos.

A oscilação entre o comum e o extraordinário nota-se, sobretudo, no jogo verbal que circunscreve os seres de Juiz de Fora, pois, sem merecer um fragmento específico como os até aqui comentados, eles são fundamentais para se apreender o insólito das conexões produzidas pelas palavras. Estas, desentranhadas de seu contexto usual, reúnem-se para sugerir imagens risíveis e surpreendentes, responsáveis pela constante e peculiar duplicidade entre a familiaridade e a estranheza da visão narrativa. Em "A rua Halfeld", relances mnêmicos vão produzindo figuras comuns, que transitam casualmente por esse espaço, tornando-as extraordinárias. O olhar "flaneur" do narrador, que conhece os passantes, impele-o a caracterizar metonimicamente Dona Aurélia como "uma montanha de babados", qualificando seu cheiro de "biscoito azedo"; a costureira Ricardina torna-se diversa e inusitada pela gradação e intensidade dos adjetivos que a descrevem - "feia, feiona, feiíssima com uma cabeleira negra, negrona, negríssima de entontecer"; Catarina, "estouvada e sardenta", ganha peculiaridade pelos inexplicáveis "olhos bicudos"; Santinha, "deliciosamente vulgar", delineia-se pelas associações sonoras e sensuais, mas inesperadas, dos termos "petulante, peitulante, rebola as ancas, à vontade do mundo"; D. Perpétua se distingue por ser "riquíssima em pés de galinha"; D. Rosalina por seus "olhos putais" e "boca reclame"; "as desgraciosas irmãs" Lúcia e Lucíola fazem um "penteado desleixado", não subscrito pelo narrador; Dona Gertrudes, "lambisgoia e múmia pré-natal", literalmente, "já nasceu fora de moda"; a cantora Risoleta tem "braços explosivos" e "olhos em itálico" e a lista poderia se prolongar, principalmente, se os seres masculinos também fossem aqui contemplados.

Em linhas gerais, conforme bem observado por Antonio Candido, há uma fusão de rasgos antagônicos, já assinalada por Manuel Bandeira, para quem Murilo é um "conciliador de contrários", incorporando o "eterno ao contingente". Os procedimentos inventivos de Murilo apontam, analogicamente, algo do trabalho onírico e da sobredeterminação, sublinhada em Drummond. As imagens que particularizam as personagens vêm de universos distintos, deslocando palavras de seus 
contextos e as condensando em outro, abrindo ao leitor uma série de interpretações distintas como se seu conteúdo manifesto, deformado, contivesse o pensamento latente do narrador. À guisa de exemplo, a impressão de máscaras das personagens (as viúvas, por exemplo) permite não só pensar a questão belo/feio, mas também a dissimulação de ambas (basta recordar do atentado sexual ao narrador ou do desprazer de tomar sopa pela presença do retrato de um morto no prato) e, além disso, elas remetem às figuras de Ensor. Sempre intrigado, o leitor se pergunta: o que seriam "os olhos em itálico", expressão que concentra corpo e sinal tipográfico, de Risoleta ou "a boca reclame", reunião de corpo e publicidade, de Rosalina ou "olhos bicudos" de Catarina? Seriam intrincados, agudos, amuados, pungentes?

Esse conjunto justifica a presença de Max Ernest e seu romance colagem, pois os processos empregados em $A$ idade do serrote assemelhamse a colagens e mimetizam associações livres, estabelecendo afinidades com o trabalho psicanalítico, sem esquecer do lirismo, sempre atuante nos fragmentos. Impossível não mencionar a descrição da mãe e da madrasta: com todas as letras, a primeira, "afeiçoada ao canto e ao piano, ao morrer, "torna-se constelação" - tributo a Mário de Andrade? ; a outra, "segunda mãe [...] resume a ternura brasileira" a ponto de o narrador asseverar: "Risquei do vocabulário a palavra madastra"; Marruzko, o inusitado leão, até disporia de "clemência, talvez reservas de ternura apreendida na companhia materna, ou quem sabe ecos de canto órfico de sabiá ou arrulhos de pomba-rola[...]"; Carmem, provocadora de encanto e repulsa, tem sua ambiguidade explicitada entre a estranheza do animal e a delicadeza da flor, ou seja, "sabia ser também gentil, quase suave, tangenciando égua e papoula", etc.

Enfim, não por acaso, Candido escolhe Boitempo e $A$ idade do serrote para escrever sobre ambos, que se tocam não apenas pela (re)contrução das lembranças, mas também pelo humor delicioso e fino lirismo. Conforme o ensaísta, Drummond constrói, por meio de "seu verso seco e humorístico, o seu firme golpe de vista e a capacidade de escorço, [...] num clima de poesia e ficção, a verdade que é o mundo do eu, e o eu como condição do mundo" (p. 55). Por sua vez, pode-se dizer que Murilo constrói, num clima de ficção e poesia, a possível verdade de seu mundo de outrora por meio do irônico e erudito olhar adulto. Em síntese, os dois autores aproximamse por vários aspectos nas obras citadas, sem perder a singularidade que os marca.

E, mais, se retomássemos uma das reflexões de Doubrovsky sobre seu conceito de "autoficção", contida em "Mon dernier moi" (2010), no qual ele propõe que "o vivido se conta vivendo" e a transferíssemos para as duas obras de Drummond e Murilo, permeadas, em maior ou menor proporção, pelo traço poético, assinalado por Candido, seria possível dizer igualmente que 'o vivido se poetiza vivendo', ou seja, os acontecimentos 
da vida do sujeito lírico ou do narrador, de algum modo, se perdem, se inserem e se reencontram na trama ampla da poesia e da prosa, na qual Imaginário e Simbólico se transfiguram nos versos e fragmentos que compõem as cenas de seus escritos, espetáculo a ser oferecido ao olhar do leitor, deixando de ser mero acontecimento pessoal para se tornar cultural. Embora em certos poemas e fragmentos, o tempo verbal ocorra no pretérito, na maioria, o presente domina como se o sujeito dos poemas ou dos textos em prosa pudessem (re)viver o perdido no momento exato da fatura da criação literária. E, "a posteriori", no instante da leitura, cabe a nós (re)vivemos com ele. Prazerosamente. 


\section{Referências Bibliográficas}

BARTHES, Roland. Aula. São Paulo: Cultrix, 1980.

BIRMAN, Joel. “O rei está nu. Contrapoder e realização de desejo, na piada e no humor". In: Revista Psicologia Clínica. Rio de Janeiro, v. 22, 210.

CANDIDO, Antonio. A Educação Pela Noite E Outros Ensaios. São Paulo: Ática, 1989.

CANDIDO, Antonio. "Autobiografia poética e ficcional de Minas". In: IV Seminário de Estudos Mineiros. Belo Horizonte: Edições do Cinquentenário da Universidade Federal de Minas Gerais, 1977.

CANDIDO, Antonio. Literatura e Sociedade. São Paulo: Companhia Editora Nacional, 1973 (3 ${ }^{\mathrm{a}}$ ed).

DRUMMOND DE ANDRADE, Carlos. Boitempo $\mathcal{E}$ a falta que ama. Rio de Janeiro: Sabiá, 1973 (2 $2^{\mathrm{a}}$ ed.).

FREUD, Sigmund. Carta 52 (1896). In: Obras completas (v. 1). Rio de Janeiro: Imago, 2006.

FREUD, Sigmund. "Recordar, repetir, elaborar" (1914). In: Obras Completas (v. 10). São Paulo: Companhia das letras, 2010.

FREUD, Sigmund. "O humor" (1927). In: Obras Completas (v. 17). São Paulo: Companhia das letras, 2010.

FREUD, Sigmund. "A história do movimento psicanalítico, artigos sobre metapsicologia e outros trabalhos". In: Obras Completas (v. 14). Rio de Janeiro: Imago, 2006.

LACAN, Jacques. Le séminaire/livre XI. Les quatre conceptes fondamentaux de la psycahanalyse. Paris: Seuil,1973.

LACAN, Jacques. Le séminaire/ livre I. Les écrits techiniques de Freud. Paris: Seuil, 1975.

MENDES, Murilo. A idade do serrote. São Paulo: Cosac \& Naif, 2014.

MERQUIOR, José Guilherme. A astúcia da mímese (ensaios sobre lírica). Rio de Janeiro: José Olympio, 1972.

PARISOT, Henri (éd). Avant-propos à Victor HUGO, ...La Bouche d'ombre. Paris: Gallimard, 1943.

PÉGUY, Charles. "Victor-Marie, comte Hugo". In: Les Cahiers de la Quinzaine, XIIe série, $1^{\text {er }}$ cahier, octobre 1910.

ROUDINESCO, Elisabeth; PLON, Michel. Dictionnaire de la psychanalyse. Paris: Fayard, 1997.

Cleusa Rios P. Passos é professora titular livre-docente do Departamento de Teoria Literária e Literatura Comparada da Universidade de São Paulo. É autora dos livros As armadilhas do Saber. Relações entre Literatura e Psicanálise (2009), Guimarães Rosa: do feminino e suas estórias (2000), Confluências crítica literária e Psicanálise (1995) e O outro modo de mirar. Uma leitura dos contos de Julio Cortázar (1986). Contato: clerios@usp.br

ORCiD: https:// orcid.org/0000-0001-6033-3112 